\title{
Rekabetçi Devlet Modelinin Maliye Politikasına İlişkin Teorik Değerlendirmesi*
}

\author{
Mustafa Alpin GÜLŞEN**, Ali Gökhan GÖLÇEK ${ }^{* * *}$
}

ÖZ

Küreselleşme bir bütün olarak sosyal ve iktisadi yapıda değişliklere neden olmuştur. Bu değişiklikler sadece hane halkı ve firmaları değil, aynı zamanda kamu kesimini ve onun maliye politikalarını da etkilemiştir. Bu etki, tıpkı özel kesimdeki rekabet anlayışında olduğu gibi kamu kesiminin de rekabetçi bir yapıya dönüşmesine yol açmıştır. Bu açıdan kamu kesimi, rekabetçi maliye politikalarıyla küresel piyasalardaki gücünü artırmaya çalışmaktadır. Çalışmada söz konusu maliye politikaları rekabetçi devlet kuramı çerçevesinde ele alınmakta ve mali rekabet, içsel devalüasyon, mali devalüasyon ile inovasyona yönelik maliye politikaları kapsamında değerlendirilmektedir.

Anahtar Kelimeler: Rekabetçi Devlet, Maliye Politikaları, İnovasyon

JEL Sinıflandırması: E62

\section{Theoretical Assessment of Competitive State Model on Fiscal Policy}

\begin{abstract}
Globalization has caused changes in the social and economic structure. These changes not only affected households and firms, but also the public sector and its fiscal policies. This effect led to the transformation of the public sector into a competitive structure, just as it was in the private sector. From this point of view, the public sector is trying to increase the power of global markets with its competitive fiscal policies. In the study, the mentioned fiscal policies are considered within the framework of competitive state theory and are evaluated within the scope of fiscal policies for fiscal competition, internal devaluation, fiscal devaluation and innovation.
\end{abstract}

Keywords: Competitive State, Fiscal Policies, Devaluation, Innovation

JEL Classification: E62

Geliş Tarihi / Received: 13.01.2019 Kabul Tarihi / Accepted: 22.03.2019

\footnotetext{
* 14 Eylül 2018'de Ankara'da düzenlenen FSCongress 2018 Quo Vadis Social Sciences adlı sempozyumda sunulan tebliğin genişletilmiş halidir.

** Öğr. Gör., Akdeniz Üniversitesi, Kumluca MYO, Finans Bankacılık ve Sigortacıllk Bölümü, m.alpingulsen@gmail.com, ORCID: 0000-0002-2860-4469.

*** Arş. Gör., Niğde Ömer Halisdemir Üniversitesi, İIBF, Maliye Bölümü, aligokhangolcek@ohu.edu.tr, ORCID: 0000-0002-7948-7688.
} 


\section{GíRiş}

Küreselleşmeyle birlikte toplumsal, siyasal ve iktisadi yapı bir bütün olarak değişiklik göstermiştir. Firmaların ulusal piyasadaki kar maksimizasyonuna yönelik rekabetçi davranış1, bireylerin sosyal hayattaki fayda maksimizasyonuna yönelik rasyonel davranışları ve kamu kesiminin uzlaştırıcı ve/veya düzenleyici politikaları günümüzde artık geleneksel kavramlarla açıklanamamaktadır.

Küreselleşmenin söz konusu aktörlerde oluşturduğu değişim ve bu değişimin etkileri üzerine, siyaset bilimi, sosyoloji ve politik iktisat literatüründe birçok çalışma bulunmaktadır. Mevcut çalışma ise bu hususlara değinmemekte, küreselleşme ile birlikte hızlanan ve gittikçe güçlenen rekabet anlayışının maliye politikalarını nasıl şekillendirdiğini açıklamayı hedeflemektedir. $\mathrm{Bu}$ açıdan çalışmada küreselleşmenin derin ve geniş boyutları ile iktisat literatüründe yer alan Schumpeterci rekabet devleti gibi hususlara geniş bir yer verilmemektedir. Ek olarak mevcut çalışmanın konusuyla ilgili yapılan niceliksel çalışmalara, kısaca değinilmektedir.

Çalışmanın ilk bölümünde rekabet devletinin kavramsal çerçevesine yer verilmektedir. Buna göre rekabet devleti (veya rekabetçi devlet) 1970'li yıllarda ortaya çıkan ve küresel piyasalarda rekabet gücünün artırılmasını ve böylece ihracatta üstün olarak döviz girdilerini yükseltmeyi hedefleyen bir organizasyon olarak ortaya çıkmaktadır. Bu açıdan ikinci bölümde küreselleşme bağlamında ele alınan rekabet devleti, kar güdüsüyle hareket eden girişimci tipolojisiyle ulusal veya küresel piyasalarda hareket etmemekte, kıt kaynakları yüksek üretkenlik ve verim sağlayan alanlara tahsis eden bir yapı göstermektedir. Buna göre geleneksel devletten farklı olarak rekabet devleti, piyasa başarısızlığına karşı vergi ve sübvansiyonlardan daha çok küresel piyasalardaki değişime uyum sağlayan, hızlı çözüm üreten ve verimliliği arttırmaya yönelik çözümleri bürokratik önlemler ile değil, girişimci basiretliliğiyle üretmektedir. Söz konusu çözümleri nasıl aldığı ise çalışmanın üçüncü bölümünde ele alınmıştır. Buna göre rekabet devletinin küresel piyasalardaki rekabetini artırmaya yönelik aldığı maliye politikaları önlemleri, mevcut çalı̧̧mada, mali rekabet, içsel ve mali devalüasyon ile inovasyona yönelik maliye politikalarından oluşmaktadır. Mali rekabet ile vergi teşvikleri ve sübvansiyon; içsel devalüasyon ile ücretlerin düşürülmesi yoluyla iç talebi azaltmak ve böylece ihracata konu olan malların ihracatını artırmak; mali devalüasyon ile işveren üzerindeki sosyal güvenlik katkı paylarının azaltılmasıyla eş zamanlı olarak dolaylı vergilerin artırılması ve bu şekilde ihracatı artırarak küresel rekabette ucuz mal üretimi sağlanması hedeflenmektedir. İnovasyona yönelik uygulanan maliye politikaları ise talep ve arz yanlı olarak uygulanmakta; inovasyon firmalarının üretimini artırmak ve/veya tüketicilerin taleplerini artırmak; kısacası üretim ile tüketimin uyumunun sağlanması hedeflenmektedir. Mevcut çalışma, söz konusu üç bölümü takiben, sonuç kısmıyla sonlandırılmaktadır.

\section{KAVRAMSAL ÇERÇEVE}

Rekabet devleti, 1970'li yıllardan itibaren gelişmiş Batı toplumlarında ortaya çıkan ve günümüze kadar dünya genelinde yaygınlaşan bir devlet biçimi olarak ifade edilebilir. Özellikle refah devletinden rekabet devletine dönüşümün, devletlerin kapitalist sistem temelli kurgulanmalarına zemin hazırladığı söylenmektedir (Cerny, 1997; Jessop, 2002). Öyle ki sosyal devletin fonksiyonlarını yerine getiren devlet, aynı zamanda toplumu rekabet içine sokan yasal düzenlemeler yapmaktadır. Bunu yaparken sosyal devlet fonksiyonlarını kademeli olarak kesmekte veya yeniden düzenleyerek rekabet ortamına zemin hazırlamaktadır (Jessop, 2002: 258). Özetle, refah devleti sosyal haklar ve koruma hizmetlerini sağlayarak, uluslararasi ekonomik ilişkileri kontrol altında tutmakta ve bunu zararlı rekabetten korunmak için 
yapmaktadır. Ancak rekabet devletinde bu durum pazarlık ve rekabet ortamının artması sonucunu doğurmaktadır (Cerny, 1997: 259). Daha yalın bir ifadeyle refah devleti kapitalizmi evcilleştirirken (Genschell ve Seelkpf, 2014: 234), rekabet devleti sermayeyi daha da hırslandırmak üzerine kurulmuştur.

Rekabet devletini bir tanım olarak ifade etmekten ziyade, özellikleri itibariyle sınırlarını ve hedeflerini belirlemenin daha doğru bir yöntem olacağından hareketle, şu gibi özelliklerinin olduğu söylenebilir (Genschell ve Seelkpf, 2014: 239; Torfing, 1996: 372-373): (i) İlk olarak, rekabet devleti, Keynesyen bir refah devleti modelini ifade etmemektedir. Rekabet devleti, makroekonomik politikalar veya ekonominin mikro ekonomik verimliliği gibi hususlarla nispeten daha az ilgilidir. Ek olarak talep yanlı bir politika tercihinden ziyade arz yanlı iktisadi politikaları tercih etmekte; mali genişlemenin aksine (mali kural gibi) mali kısıtlamayı, artan oranlı (kademeli) vergileme yerine nötr vergilemeyi ve en önemlisi tam istihdamdan ziyade enflasyon kontrolünü öncelikli hedef olarak görerek aktif sektörel politikalar yerine inovasyonu ve büyümeyi amaçlamaktadır. Dolayısıyla rekabet devleti piyasa mekanizmalarına dayanmakta ve piyasaya yönelik kamu kesimi müdahalelerinden kaçınmaktadır. (ii) İkinci olarak rekabet devleti, tüketicilerin ve sektörlerin piyasa bağımlılı̆̆ını azaltmak yerine, artırmayı amaçladığı için bir refah devleti olarak düşünülmemektedir. Bu açıdan rekabet devleti, vatandaşların işsizlik yardımı alması yerine ücret karşılı̆̆ piyasada yer almasını sağlamakta ve bir maliye politikası aracı olarak sübvansiyonlarını istihdam ve eğitim programlarına (aktif işgücü piyasası politikasına) tahsis etmektedir. Bu kapsamda rekabet devleti, piyasanın gelişmesine önemli katkıda bulunmakta ancak piyasa sonuçları hakkında herhangi bir garanti vermeyi reddetmektedir. (iii) Üçüncü olarak rekabet devleti, ulusal ekonomi politikalarına odaklanmaması nedeniyle temel anlamında ulusal bir devlet olarak görülmemektedir. Refah devletine ait iktisadi politikalar genellikle sermaye kontrolleri ve ticaret kısitlamaları ile kapalı bir şekilde kendi kendine yeten ekonomik yapıda kendini gösterirken; rekabet devleti daha çok uluslararası ticarete ve sermaye akımlarına açılmakta ve böyle ulusal ekonomiyi küresel pazarlara açarak sadece ulusal ekonomide faaliyet göstermemektedir. Bu açıdan refah devletinin aksine rekabet devleti, ortak hedeflere yönelik pragmatik bir birlikteliği ön plana koymaktadır. (iv) Son olarak rekabet devleti, küresel yatırımcıların taleplerini kamusal alanda uygulayan bir modelde varlığını göstermektedir.

Dolayısıyla kamu kesiminin ekonomideki rolüne ilişkin Keynesyen refah devleti yaklaşımı, yerini Rekabetçi devlet modeline bırakmıştır. Bu modelin temel argümanları ise enflasyon kontrolü, inovasyon ve müdahalesiz piyasa ekonomisi gibi neoliberal iktisat yaklaşımlarından oluştuğu ifade edilebilir. $\mathrm{Bu}$ açıdan uluslararası ilişkiler literatüründe devletlerin siyasal olarak birbirine bağımlılığını ifade eden karşslıklı bağımlılık kavramı (Cerny, 1996:622), rekabet devleti anlayışında bu kez siyasi olarak değil iktisadi olarak karşımıza çıkmaktadır.

\section{KÜRESELLEŞME BAĞLAMINDA REKABET DEVLETİ}

Genel olarak kamu kesiminin, özel anlamda ise hükümetlerin tüm dünyada karşılaştıkları en büyük zorluklardan birisi, küreselleşmeye uyum sağlama kapasitelerini geliştirmek ve bu açıdan hem ulusal hem de uluslararası politikaları bütünleştirmek olarak ifade edilebilir. Kamu kesimi ile piyasa arasındaki sınırın belirlenmesinde talep yanlı ve arz yanlı iktisat kuramları iki önemli iktisadi fikri öne sürmekte ve özellikle 1920'ler itibaren kamu kesiminin üretici, dağıtıc1 veya piyasaları regüle edici rolünün olması hususlarında dikkatleri bu iki aktör arasındaki ilişkinin ne olması gerektiğine çekmiştir. Ancak söz konusu tarihsel süreç içinde bu politikaların temel varsayımı, uluslararası sermayeye karşı güçlü bir özerklik alanının bulunmasına yönelik olmuştur. Bir diğer ifadeyle kamu kesimi ile piyasa arasındaki sınırın boyutu ne olursa olsun, kamu kesiminin kendi has ve nispeten güçlü bir özerklik alanı bulunmaktaydı. Fakat 
küreselleşme ile birlikte bu tür bir özerklik gittikçe daha fazla sınırlandırılmakta; kamu kesiminin gücü ve istikrarı zayıflamaktadır (Cerny ve Evans, 2000:1).

Küreselleşme ile ilgili tanımlar genellikle ekonomik ve sosyal gelişme bağlamında yapılmakta ve bu açıdan iki temel ayrımla ifade edilmektedir. Bu ifadelerden birincisi, üretim, bölüşüm, yönetim ve finans gibi iktisadi ya da kültür, iletişim ve ideoloji gibi sosyal hususlarla ilgiliyken; ikinci önemli ayrım ise küreselleşmeyi destekleyenler ile desteklemeyenler arasında yapılmaktadır. Tablo 1'de küreselleşmenin bu boyutları gösterilmiştir.

Tablo 1: Küreselleşmenin Boyutları

\begin{tabular}{|c|c|c|}
\hline & Küreselleşmenin Sonuçları \\
\hline Küreselleşme Türü & Desteklemeyenler & Destekleyenler \\
\hline Dar: İktisadi & $\begin{array}{c}\text { İktisadi olarak karşılıklı bağımlılı̆̆a } \\
\text { yol açar }\end{array}$ & $\begin{array}{c}\text { Küreselleşmiş ekonomik bir sistem } \\
\text { niteliksel değişime yol açar }\end{array}$ \\
\hline $\begin{array}{c}\text { Geniş: Tüm sosyal } \\
\text { Dönüşümler }\end{array}$ & $\begin{array}{c}\text { Karşılıklı bağımlılığın artmasına yol } \\
\text { açar }\end{array}$ & $\begin{array}{c}\text { Küreselleşmiş bir toplum, bireylerin ve/veya } \\
\text { grupların yaşam koşullarının yeniden } \\
\text { tanımlanmasına yol açar }\end{array}$ \\
\hline
\end{tabular}

Kaynak: Sorensen, 1998: 94.

İkinci önemli ayrım, küreselleşmeyi destekleyenler ile desteklemeyenler arasındadır. $\mathrm{Bu}$ ayrıma göre küreselleşmeyi desteklemeyenler bir bütün olarak devletin iktisadi ve sosyal açıdan diğer devletlere ve/veya toplumsal dinamiklerine bağımlı olacağını ileri sürmekteyken, küreselleşmeyi savunanlar bu sürecin yeni başlamadığını; uzun yıllardır var olan bu gelişmenin bireysel ve toplumsal açıdan niteliksel bir değişime yol açtığını ileri sürmektedir (Sorensen, 1998: 93-94).

Küreselleşme ile birlikte meydana gelen iktisadi ve sosyal dönüşümde rekabetçi devlet, toplumsal çıkarlar arasında bir hakem olarak değil; küresel iktisadi alanda daha çok oligopolistik güçlerin yanında olduğu ileri sürülmektedir (Dardot ve Laval, 2014: 222). Bu çerçevede küreselleşme bağlamında rekabet devleti, girişimci devlet modelini benimsediği söylenebilir. Buna göre küreselleşme ile birlikte değişen hızlı iktisadi ve sosyal dinamiklere karşı bürokratik çözümler yerine girişimci önlemler alınmaktadır. Söz konusu devlet, piyasada oluşan başarısızlığa karşı kamusal mal ve hizmetler üretmek, vergileri veya sübvansiyonları kullanmak gibi yöntemler yerine değişime uyum sağlayan, hızlı çözüm üreten, verimliliğini sürekli arttıran; kısacası girişimci bir aktör olması gerekmektedir. Söz konusu girişimcilik vurgusu, kar için örgütlenen bir kurumsal yapıyı ifade etmemekte; kıt kaynaklarını düşük üretkenlik ve minimum getiri alanlarından yüksek üretkenlik ve verimli alanlara yönlendiren bir anlam taşımaktadır. Bu kapsamda küreselleşme bağlamında rekabet devleti, piyasaları canlandırmak için kullandığı tekel yapılanması yerine günümüzde, rekabete dayalı bir politik çözümü benimsemektedir (Osborne, 1993: 349-352).

Genel olarak bakıldığında rekabet devleti, 1970'lerin ortalarından itibaren küresel düzeyde eşitsiz bir şekilde ilerleyen devlet-toplum ilişkilerinin neoliberal yeniden yapılanmasına karşıllık gelmesi olarak ifade edilmektedir (Taylor, 2010: 40). Bununla birlikte her ne kadar neoklasik iktisat ile ilişkilendirilse de rekabet devletinde piyasaya müdahale devam etmekte; küreselleşme sürecinde uluslararası piyasalar ile rekabet edebilmek amacıyla piyasa aktörlerinin muhtemel maliyetlerini düşürmeye yönelik politikalar izleyebilmektedir. Bu açıdan piyasaların özel sektöre bırakılması sonucunda, firmaların sağlayamadığ 1 veya güçlendiremediği rekabet olgusu, devlet tarafından üstlenilmiş; küresel piyasalarla ve özellikle çok uluslu şirketlerle ulusal firmaların 
rekabet edebilmesi veya rekabet gücünün arttırılmasına yönelik devlet, sorumluluk üstlenmiştir. $\mathrm{Bu}$ nedenle kamu kesimi, kamusal kaynakların tahsisinde rekabeti pozitif yönde etkileyici harcama kalemlerine fonları tahsis etmektedir.

Diğer yandan ismini Joseph Schumpeter'den alan Schumpeterci yaklaşım ise devletin rekabet edilebilirliğini, diğer ülkelerden inovasyon açısından üstünlüğüne bağlamaktadır. $\mathrm{Bu}$ inovasyonun kapsamı ise teknoloji, üretim, organizasyon ve piyasalar olarak belirtmektedir. Keynesyen yaklaşımdaki özellikle kapalı ekonomi vurgusu, günümüzdeki küreselleşme ve uluslararası rekabeti açıklamada yeterli olamaması Keynesyen refah devletinden uzaklaşılmasına da yol açmıştır. Dolayısıyla Schumpterci rekabet devletinin rekabet etme gücü, onun küresel gelişmelerle tutarlı ve hatta bu gelişmelerin ötesine de giden bir şekilde, teknoloji ve üretimin yanı sıra devlet organizasyonun (kurum ve kuruluşların, bürokratik örgütlemenin) ve piyasaların (tüm sektörlerin) inovasyondaki başarısıyla ilişkili olmaktadır. Bu şekilde politik karar alıcıların üretim maliyetini düşürerek ve yeni pazarlar arayarak rekabet avantajlarını kendi lehine çevirerek de rekabet sağlamış olmaktadır. $\mathrm{Bu}$ süreç, beraberinde diğer inovasyonların yapılmasını sağlayarak, devletin rekabeti hususunda pozitif bir katkıda bulunabilmektedir (Jessop, 2002: 121-124). Dolayısıyla Schumpterci rekabet devleti anlayışında, kamu kesimi piyasalara doğrudan veya dolaylı şekilde müdahale etmek yerine ülkedeki inovasyonu artırarak ekonominin büyümesini ve böylece ulusal zenginlik hedefine ulaşmayı ifade etmektedir. Bir diğer ifadeyle ekonomiye özellikle maliye politikaları ile doğrudan veya özellikle regülasyonlar ile dolaylı müdahale yaparak Keynesyen refah devletine ulaşmak yerine Schumpeterci bir refah devletine ulaşmayı hedeflemekte olduğu ileri sürülebilir. ${ }^{1}$ Dolayısıyla serbest piyasanın, paranın ve vergilemenin arz yanlı etkilerinden ziyade sermaye birikiminin veya büyümenin merkezinde inovasyon kavramı bulunmaktadır (Jessop, 1993: 21).

\section{REKABET DEVLETI VE MALIYE POLITIKALARI}

Küreselleşmeyle birlikte maliye politikalarının amaçları ve araçları değişiklik göstermiştir. $\mathrm{Bu}$ süreçte geleneksel maliye politikaları yerine özellikle teknolojik gelişmeye uyum sağlayan ve hatta onun üzerine çıkan uygulamalara odaklanılmıştır. Günümüzde, küresel rekabette önemli bir konum almak isteyen ulusal ekonomiler birçok politika aracını kullanmaktadır. Mevcut çalışmanın kapsamında ele alınacak bu politikalar, bütün bir sistemi açıklamamakta ancak önemli görülen politik araçlar olarak görülmektedir. Buna göre rekabet devleti anlayışıyla hareket eden ulusal ekonomilerin küresel ticaret ve finansal piyasalarda yerini alabilmek için mali rekabet, içsel devalüasyon, mali devalüasyon ve inovasyona yönelik maliye politikalarını kullanmaktadir.

Mali rekabet ile rekabetçi devletler, vergi rekabetleri yoluyla vergi teşvikleri ve vergi tatilleri konusunda rakip ülkelerle rekabet halinde olmakta; sübvansiyonlar yoluyla da yatırımcılara cazip bir ülke olma hususunda politik tercihler sunmaktadır. Bu açıdan mali rekabet, maliye politikasının geleneksel araçlarını kullanmakta; firmaların maliyetlerini

\footnotetext{
${ }^{1}$ Keynesyen Refah devletinden rekabet devletine geçişle birlikte Schumpeterci refah rejimine doğru bir dönüşüm yaşanmaktadır. Bununla birlikte her iki yaklaşım, sermaye ile emek kesimi arasındaki çatışmalı ilişkiyi yönetmek için düzenleyici yapılar olarak görülmektedir. Temel anlamda Keynesyen refah devletinin amacı, tam istihdam ve kitlesel tüketimin ve üretimin yaygınlaştırılması ve bunun sonucunda da büyük bir sosyal güvenlik programının ortaya çıkması; Schumpeterci refah rejiminin amacı ise yenilikçiliğin ve özellikle emek piyasalarında esnekliğin artırılması olarak ifade dilebilir. Bu anlamda her iki yaklaşım birbirinden önemli ölçüde ayrılmaktadır (Vis, 2007: 3). Keynesyen refah devletine göre, sosyal yardıma ihtiyaç duyan kişiler için kamu kesimi bir tür yardım sağlaması gerekmektedir. Keynesyen refah devletinin mantığına doğrudan ters düşen Schumpetarci refah devleti ise tüm refah katılımcılarının (vatandaşların) sömürücü çalışma koşullarına rağmen emek gücünün bir parçası olmasını şart koşmaktadır (Pinder, 2011: 185).
} 
toplumsallaştırmaktadır. Rekabet gücünü çalışanların ücretlerini düşürmek suretiyle hem işveren maliyetini hem de kişi başı satın alma gücünü azaltan içsel devalüasyon yönteminde ise temel hedef, yurtiçinde üretilen ihracata konu olan malların tüketilmesini azaltarak ihracat artışının sağlanması ve böylece rakip ülkede üretilen mal ve hizmetlerden daha ucuza üretim yapmak olarak kendini göstermektedir. İçsel devalüasyona temelde benzeyen ancak yöntem olarak oldukça farklı bir rekabet gücü kazandırdığı düşünülen mali devalüasyon da ise işveren üzerindeki sosyal güvenlik katkı paylarının azaltılması ve/veya alınmamasıyla eş zamanlı olarak oluşan mali açığın, dolaylı vergilere yansıtılması yoluyla nominal ücretlerin düşürülmesi ve böylece işverenin üretimi artırılması hedeflenmektedir. $\mathrm{Bu}$ yöntemde işverenin üretim maliyetinin azalması nedeniyle ihracata konu olan malların üretimi artmakta, bununla birlikte kişisel satın alma gücünün düşmesi nedeniyle söz konusu malların tüketiminin azalması ve sonuç olarak ihracatın artırılması hedeflenmektedir. Ancak içsel devalüasyonda olduğu gibi mali devalüasyonda da istenen hedeflere ulaşılamamış, uygulandığı ülkelerde işsizliğin artmasının yanında sosyal sorunlara sebep olmuştur.

Mevcut çalışmada yer alan yöntemler arasında nispeten daha net çıktısı olan, iktisadi yapıya pozitif etkisinin doğrudan görüldüğü rekabeti artırma seçeneğinin inovasyona yönelik uygulanan maliye politikalarının olduğu ifade edilebilir. Bu yöntemde kamu kesimi inovasyona yönelik talep ve arz taraflı maliye politikaları uygulamaktadır. Her iki taraf arasında Keynesyen ve Neoklasik gibi keskin bir ayrım bulunmayan; birbirini tamamlayan bu politikalardan talep taraflı inovasyon politikalarında kamu kesimi, inovasyon firmalarından doğrudan mal ve hizmeti alımı yapabildiği gibi regülasyonlarla veya bilinçlendirme kampanyalarıyla da talebi dolaylı olarak etkilemektedir. Ek olarak inovasyona yönelik arz yanlı maliye politikasında ise kamu kesiminin inovasyon firmalarına yönelik vergi teşvikleri gibi yöntemlerle doğrudan etkilerken, onlara rehberlik etmesi ve yeni piyasalara girmesi açısından da dolaylı etkide bulunmaktadır.

\subsection{Mali Rekabet ve Rekabetçi Devlet}

Mali rekabet kavramı, şirketlere yönelik uygulanan vergi tatilleri veya indirimi gibi dolaylı şekilde veya örneğin altyapı projelerine doğrudan verilen sübvansiyon gibi desteklerle kamu kesimi tarafından finanse edilmeyi ifade etmektedir (Wildasin, 2006: 502:1). Bu aç1dan mali rekabeti, maliye politikasının geleneksel vergi ve sübvansiyon araçları ile ele almak mümkün gözükmektedir.

Küreselleşme ile birlikte ekonomik entegrasyon arttıkça, bireyler ve işletmeler özellikle yabancı ülkelerdeki ekonomik firsatlardan yararlanmak açısından özgürlük alanı oldukça genişlemiş; bunun sonucunda ise yatırım kararlarında mekân unsurunun vergilendirilmeye olan duyarlılığı artış göstermiştir. Diğer taraftan ulusal ekonomiler ise söz konusu duyarlılığ 1 kabul eden taraf olarak vergi mükellefiyetinin koşullarını iyileştirmek veya vergi tabanlarını azaltmak zorunda kalmıştır. Bu açıdan vergi rekabeti ${ }^{2}$, sermaye ve emek hareketliliği arttıkça, artan yönde kendini göstermektedir. Buna paralel olarak da çoğu sanayi ülkesi, ekonomilerinin yatırım için cazip olmasını sağlamak amacıyla vergi reformları yapmaktadır. Genellikle vergi indirimlerine yönelik bu reformlar ile oluşturulan vergi rekabeti, ülkelerin birbirlerine uyguladıkları vergi politikası etkisini de içerecek şekilde geniş şekilde tanımlandığında, komşu ülkelerin uyguladığı düşük vergi oranlarının başarılı olması sonucunda vatandaşlar ve politika uzmanları da kendi politikacılarından bunu talep edebilmektedirler (Edwards ve Rugy, 2002: 3). Dolayısıyla vergi rekabeti, ekonomideki aktörlerin stratejik değişkenlerinin vergi oranları olmadığı bir ortamı ifade etmektedir (Madiès ve Dethier, 2012: 5).

\footnotetext{
${ }^{2}$ Vergi rekabetiyle ilgili ilk çalışmalar Zodrow ve Mieszkowski (1984) ve Hoyt (1991) tarafından ele alınmakta ve söz konusu kavram kamu finansmanı ve mali federalizm literatürüne dayanmaktadır.
} 
Diğer taraftan söz konusu rekabette ülkelerin büyüklüğü de önem taşımaktadır. Mevcut çalışmanın konusunu oluşturmadığından kısaca değinilecek olan asimetrik vergi rekabeti denilen bu rekabette küçük ülke, vergi oranını belirleyerek net sermaye ithalatçısı iken; büyük ülke daha yüksek vergi oranı belirlediğinden net sermaye ihracatçısı olarak kabul edilmektedir. Ancak bu durumda büyük ölçekli ülke, küçük ülkeden daha fazla vergi indirimi yapabilme imkanına sahip olduğundan; bir diğer ifadeyle küçük ülkeler büyük ülkelere kıyasla vergi oranlarını daha düşük belirleme eğiliminde olduğundan, bu sürecin sonunda küçük ölçekli ülkenin zararlı çıkacağı öne sürülmektedir. (Bucovetsky, 1991: 178; Wilson ve Wildasin, 2004: 1075)

Literatürde oldukça geniş bir yer kaplayan vergi rekabeti hususundan kısaca bahsedilmesinin ardından, rekabet devletinde görülen bir diğer maliye politikası ise vergi teşviki ve sübvansiyonlar olarak ifade edilebilir. Yabancı çok uluslu firmalar için vergi tatilleri, vergiden muaf tutulmak ya da ülke piyasasına girişten sonra sınırlı bir süre için verilen doğrudan sübvansiyonlardır (Doyle ve Wijnbergen, 1994: 211). Söz konusu iki politika seçeneği de yine vergi rekabetinde olduğu gibi ülkelerin mali potansiyel gücüyle orantılı şekilde yapacağı vergi tatilleri veya teşvikleri ile sübvansiyonlarının, ülke ekonomisini yatırımcılara karşı cazip kılmasına neden olmaktadır. Ancak politikacıların önceden belirlediği veya gelme olasılığı olan yatırımcilarla pazarlık sonucu belirlenen vergi tatilleri veya vergi teşviklerinin ve sübvansiyonların boyutuna ilişkin varılan anlaşmalara, politikacıların güven zedeleyici bir eylemi veya politikayı uygulamaması gerekmektedir. Aksi halde küresel piyasalarda, söz konusu ülke ekonomisine karşı negatif bir imaja neden olarak, diğer dönemlerde yapılacak teşviklere olan güven duygusu azalma eğilimine girecektir. $\mathrm{Bu}$ ise yatırımcıların bu ülkeye gelmemesi gibi ülke ekonomisi açısından oldukça olumsuz bir sürece girilmesine neden olacaktır.

Vergi rekabetleri, vergi politikaları ortak olmayan veya bağımsız olarak seçen iki veya daha fazla ülke arasında gerçekleşmekte ve böylece her biri için mevcut olan vergi tabanlarının boyutunu etkilemektedir. Ancak düşük vergi oranı, kamu harcamalarının azalmasına neden olarak sosyal refahı düşürme riskini de taşımaktadır. Buna bir çözüm olarak düşünülebilecek vergi uyumlaştırması, vergi rekabetinin etkilerini azaltma ya da ortadan kaldırma amaciyla eşgüdümlü bir şekilde kabul edilen (asgari veya tek bir oran gibi) kurallar kümesini oluşturmakta; bu ise ülkelerin rekabet sonucu refahlarının azalmasını engellemektedir (Karmakar ve Martines-Vazguez, 2014: 4-5). Vergi rekabetinin ulusal ekonomilere vereceği zararı azaltmaya yönelik önerilen vergi uyumlaştırılması aynı şekilde vergi teşviklerinde ve sübvansiyonlarında da uygulanabilir. Ulusal ekonomiler örneğin sübvansiyon rekabetine girerek kamu kaynaklarının önemli bir bölümünü bu hedefe tahsis ederek sosyal harcamalarını aynı oranda azaltma eğilimine girebilirler. $\mathrm{Bu}$ süreç ise beraberinde, efektif talebin azalmasından sağlık ve eğitim gibi sosyal refahı pozitif yönde etkileyen kamu hizmetlerinin üretilememesine kadar birçok olumsuz sonuçları getirebilir.

\section{2. İçsel Devalüasyon ve Rekabetçi Devlet}

1980'li yılların sonlarında Fransa tarafindan orta vadede uygulanan rekabetçi enflasyondaki düşüş politikası, içsel devalüasyon stratejisinin ilk örneklerini oluşturmaktadır. AB'ye üye ülkeler ulusal paralarını ve döviz kuru politikalarını bağımsız bir şekilde kullanmaktan vazgeçmeleri nedeniyle, Avrupa para birliğinin istikrarlı şekilde işleyebilmesi için ücret ve fiyat esnekliği gerekmektedir (Uxo vd., 2014: 2). Ulusal para birimlerini kullanamadıklarını için klasik anlamda parasal devalüasyon yapamayan Avrupa Birliği ülkeleri, küreselleşmeyle beraber meydana gelen birçok krizden sonra oluşan ulusal borç krizlerine çözüm olarak, genellikle Avrupa Komisyonu, Avrupa Merkez Bankası ve Uluslararası Para Fonu tarafından verilen kurtarma kredileri, ekonomik uyum programlarının uygulanması şartıyla verilmiştir. Söz konusu kuruluşların, krizden etkilenen ve kredi verilen ülkelere uygulanmasını önerdiği politikalardan biri, içsel devalüasyon (internal devaluation) olmuştur. İçsel 
devalüasyondan farklı olarak reel döviz kurunun değerini düşürme, ödemeler dengesi krizlerini bertaraf etmek için geleneksel bir mekanizma olarak görülmüştür. Diğer bir ifadeyle yurtiçinde üretilen mal ve hizmetlerin fiyatlarını, diğer ülkelerde üretilen mallardan nispeten daha ucuz hale getirerek cari işlemler açığının azaltılması hedeflenmektedir. Esnek döviz kuru rejimlerinin uygulandığı ülkelerde, reel döviz kurunun değerini düşürme, nominal döviz kurunun değer kaybetmesi ile kısa vadede kolaylaşmıştır. Fakat, ülkede sabit döviz kuru rejimi uygulandığında veya parasal bir birliğe girdiğinde içsel devalüasyon; bir diğer ifadeyle özellikle nominal ücretler ve fiyatlar ile üretim maliyetlerini düşürmek, kısa vadede reel döviz kurunun değerini düşürmenin tek yolu olarak görülmektedir. İlk olarak Baltık ülkelerinin kabul ettiği bu politika önermesi, bir emek maliyeti olarak ücretlerin düşürülmesini içeren mali tasarruf ve yapısal uyum reformundan oluşmaktadır. Bu açıdan içsel devalüasyon, bir ekonomideki mal ve hizmetlerin göreli fiyatlarını rakip ülkedeki fiyatlardan nispeten daha ucuza getirmekten oluşmakta; bu ise ihracatın nispeten daha ucuza ve ithalatı da nispeten daha pahalı hale getirmektir (Theodoropoulou, 2016: 9-11).

Özellikle son dönemlerde uygulanan içsel devalüasyon ile ilgili literatürde birçok çalışma bulunmakta; bu çalışmaların büyük bir bölümü söz konusu politikanın başarısızlığını ortaya koymaktadır. Bu çalışmalara örnek olarak Weisbrot ve Ray (2011) ve De Grauwe (2012) verilebilir. Bununla birlikte bu politika Keynesyen açıdan eleştirilmekte; düşen ücretlerin etkisi ile tüketim harcamalarını düşürdükleri ve ekonominin daha da negatif bir seyir izlemesine neden olduğu (Stockhammer ve Sotiropoulos, 2014: 213) ifade edilmekle birlikte, içsel devalüasyon sonucu devletin rekabet konusunda pozitif bir yol kat ettiği ancak bu artışın oldukça küçük bir oranda olduğu ve beraberinde işsizliği de artırdığı öne sürülmektedir (Armingeon ve Baccaro, 2012: 256).

Dolayısıyla küreselleşme ile birlikte ortaya çıkan rekabet devleti modeli, son dönemdeki krizlerin, ulusal ekonomilerin küresel piyasalardaki rekabetin düşmesiyle, içsel devalüasyon adıyla bir rekabetçi politika uygulamıştır. Rekabeti artırmaya yönelik söz konusu maliye politikasıyla ekonomiler, özellikle ücretleri düşürerek mali tasarruf ve yapısal uyum politikalarına yönelmiş ve böylece krizin, merkezi bütçe üzerindeki yükünün hafifletilmesi düşünülmüş̧ür. Ek olarak, krizin maliyeti böylelikle toplumsallaştırılmıştır. Bu açıdan rekabet devleti anlayışıyla uygulanan bu içsel devalüasyon yöntemi, küresel piyasalarda ulusal rekabeti artırmamış; işsizliği daha da yükselterek sosyal yapıda negatif yönlü etkilere neden olmuştur.

\subsection{Mali Devalüasyon ve Rekabetçi Devlet}

Mali devalüasyon (fiscal devaluation) kavramı kısaca, vergiler arası takas yoluyla (Pereira ve Pereira, 2014: 3) ulusal ekonomilerin küresel rekabetini arttırmaktan ziyade, işverenlerin üzerindeki sosyal güvenlik katkı payı yükünü azaltarak, burada oluşacak mali açığın, katma değer vergisinin artırılması yoluyla kapatılmasına yönelik uygulamalar olarak ifade edilebilir (Koske, 2013: 7; Meloni, 2017: 10). Bu açıdan mali devalüasyon politikaları, ulusal borç krizinden en çok etkilenen $\mathrm{AB}$ üyesi ülkeler için rekabeti yeniden tesis etmek ve nihai olarak ekonomik büyümeye katkıda bulunmayı hedeflemektedir. Söz konusu ülkeler bir para birliği içinde olmaları nedeniyle, geleneksel devalüasyon yapamadığından, işveren üzerindeki sosyal güvenlik ücret maliyetlerini düşürerek, bu düşüşü de tüketim vergileri ile bertaraf etmekte ve böylece ihracat konusu mal ve hizmetler ucuzlarken ithalat nispeten pahalı hale gelmektedir.

Bununla birlikte mali devalüasyonun başarılı olması için iki koşulun sağlanması gerekmektedir. Bunlardan birincisi, yüksek yurtiçi fiyatların daha yüksek nominal ücretlere neden olmaması gerekmekte; ikincisi ise firmalar, kâr marjını emek üzerindeki düşük vergi oranlarından çıkarmamalıdır (Caprioli vd., 2017: 16). Bu iki koşulun gerçekleşmesi halinde 
firmalar, düşen emek maliyetinin etkisiyle üretimlerini artırmakta ve ihracata konu olan mal ve hizmetlerin fiyatları rakip olan ekonomilere kıyasla ucuzlamaktadır.

İçsel devalüasyon ile mali devalüasyonun temel fark1 ise, içsel devalüasyonda rekabeti artırmak için ücretler düşürülürken, mali devalüasyonda işverenler üzerindeki işçi sosyal güvenlik katkı payları düşürülmekte ve böylece merkezi bütçede oluşan yükün tüketim vergisine aktarılmaktadır. Böylece efektif talebin büyük çoğunluğunu oluşturan ücretli kesimin nominal ücretleri düşerek yurtiçi talep azalacak ve ihracatın artması muhtemel hale gelecektir. Buna ek olarak içsel devalüasyona kıyasla mali devalüasyon ile küçük de olsa katkılar sağlamıştır. Ancak niceliksel çalışmalara göre mali devalüasyonun pozitif katkısı çoğunlukla \%1'den düşük gerçekleşmiştir. Bu çalışmalara Hohberger ve Kraus (2016), Besson (2007) ve Fève vd. (2009) çalışmaları örnek olarak gösterilebilir.

Dolayısıyla mali devalüasyon ile ihracata konu olan malların üretildiği sektörlerde işveren üzerindeki sosyal güvenlik payları azaltılarak ihracata konu olan malların üretildiği sektörlerde sosyal güvenlik katkı paylarının düşürülmesi, bu firmaların üretim maliyetlerini düşürecek ve böylelikle üretimini; dolayısıyla ihracatını artıracaktır. Bu sürecin sonunda ise yurtiçinde üretilen malların rakip olan ekonomilere kıyasla, küresel rekabet artacaktır.

\section{4. İnovasyon ve Rekabetçi Devlet}

Rekabetçi devletin, küreselleşme sürecinde sorumluluk alanına giren inovasyona yönelik politikalar izlemesi artık zorunlu olmuştur. İktisadi bir kriz içinde olup olmadığa bakılmaksızın devletler, küresel rekabete uyum sağlayacak veya mevcut seviyenin üstüne çıkacak inovatif gelişmeleri takip etmek durumundadır. Buna göre politik karar alıcılar, inovasyona yönelik yatırımları olan firmaların maliyetlerini düşürmek suretiyle yatırımlarını artıracak arz yanlı; firmaların üretimlerini tüketicilerin tercihleriyle buluşturması anlamında da talep yanlı maliye politikalarını uygulamaktadır (EC, 2015a: 9)

Rekabetçi devletin inovasyona yönelik uyguladığı maliye politikaları her ne kadar arz ve talep yanlı olarak ayrılmaktaysa da bu ayrım Neoklasik ve Keynesyen ayrım olarak değil; bu iki politika tercihi, birbirini tamamlayan unsurlar olarak görülmektedir (Roolaht, 2010: 406). Bu açıdan arz yanlı inovasyon politikaları, araştırma ve teknolojik gelişme, bilim, mühendislik ve matematik gibi konularda beşeri sermayenin artırılmasına ve yeniliği geliştirme fırsatlarının öngörülmesine odaklanmaktayken (EC, 2015b: 12); inovasyona yönelik talep yanlı maliye politikaları ise mal ve hizmetin doğrudan alımı, regülasyonlar yoluyla firmaların efektif talebe uyumunun sağlanması, talep sübvansiyonları, vergi teşvikleri ve tüketicileri bilinçlendirme kampanyalarından oluşmaktadır (Izsak ve Edler, 2011: 6). Bu kapsamda talep yanlı inovasyon politikaları, inovasyon talebini artırmak, teşvik etmek ve yenilik yaratmak amacıyla çoğunlukla kamu kesiminin önlemler seti olarak ifade edilmektedir (Edler ve Georghiou, 2007: 950).

İnovasyona yönelik maliye politikalarının ekonomik yapıya etkisi konusunda literatürde niceliksel birçok çalışma yapılmıştır. Bu çalışmaların en önemli ortak tarafı, inovasyonun örneğin istihdamı artırma, yeni firmaların ortaya çıkması ve GSYH'yi; kısacası iktisadi yapıyı bir bütün olarak pozitif yönde etkilemesidir. Bu çalışmalara Falk (2007) ve Aghion ve Howitt (1998) örnek olarak gösterilebilir.

Dolayısıyla rekabetçi devlet yaklaşımı, küreselleşen iktisadi ilişkilerde önemli bir aktör olma amacıyla inovasyona yönelik maliye politikalarına yer vermektedir. Bununla birlikte inovasyona yönelik maliye politikalarını diğerlerinden ayıran önemli bir özelliği ise diğer politikaların toplumun herhangi bir kesiminin fayda düzeyini düşürürken, inovasyona yönelik harcamalarla ilgili henüz böyle bir bulguya rastlanmamıştır. Bir diğer ifadeyle inovasyona 
yönelik maliye politikaları, diğerleriyle kıyaslandığında en net çıktıyı veren ve bu çıktının çoğunlukla iktisadi yapıyı pozitif yönde etkilemesidir.

\section{SONUÇ}

Ekonomilerin birbiriyle olan etkileşimi, küreselleşme ile birlikte hız kazanmıştır. $\mathrm{Bu}$ etkileşimin belki de en önemli unsuru, teknolojik yeniliklerdir. Üretim maliyetlerinin düşürülmesinde veya ürünün pazarlanmasında oldukça büyük öneme sahip olan bu unsur, firmalar arası rekabete devletlerin de katılmasına neden olmuştur. Bu süreçte sadece kamusal kaynakların değil aynı zamanda özel sektörün ve hane halklarının kaynaklarını da üretken alanlara yönlendirme sorumluluğu, politik karar alıcılara düşmüştür. Geleneksel bürokratik organizasyon yerine girişimci gibi hareket eden devletler, küresel rekabette üstünlüğü kurmaya yönelik politikalar geliştirmiş ve böylece ihracatı artırarak döviz girdilerini yükseltmeyi hedeflemiştir.

Rekabetçi devlet modeliyle birlikte devletin ekonomideki rolü, küresel piyasalarda rekabet gücünü artırmaya yönelik politikalarda yoğunlaşmıştır. Böylece özellikle firmaların üretim maliyetlerinin düşürülmesiyle ihracata konu olan malların üretiminin artırılması, diğer yandan tüketicilerin ve/veya ücretlilerin satın alma gücünü azaltarak ihracata konu olan malların tüketiminin yurtiçi piyasada düşürülmesi neticesinde, ihracatın artırılması hedeflenmiştir. Ancak bu politika tercihi de tek başına yeterli olarak görülmemiş, bunun yanında inovasyona yönelik talep ve arz yanlı maliye politikası uygulamalarına da yer verilmiştir.

Rekabetçi devlet anlayışında uygulanan içsel devalüasyon, diğer maliye politikalarına kıyasla, sosyal ve iktisadi açıdan negatif etkisi net olarak görülmüş ve niceliksel çalışmalarla bu etki desteklenmiştir. İşsizliği artırmasının yanında yurtiçi talebi ciddi oranda düşürmesi nedeniyle üretimi de negatif etkilemiş̧ir. Mali devalüasyonun ve mali rekabet ile ilgili hususlarda ise iktisadi gelişmeye etkisi ise niceliksel çalışmalarla geniş kapsamlı değerlendirilemese de iktisadi yapıya pozitif yönlü etkilerinin olduğu öne sürülmektedir. Söz konusu maliye politikası tercihlerinden belki de en önemlisi, inovasyona yönelik uygulanan maliye politikalarının olduğu söylenebilir. Bu politika tercihinde iktisadi yapıya etkisi hem en somut hem de güçlü pozitif katkısı bulunan inovasyona yönelik maliye politikalarıyla ilgili niceliksel çalışmaların en önemli ortak özelliği, tüm ülkelerde tüm zamanlarda iktisadi yapıya etkisinin pozitif olmasıdır. Dolayısıyla ekonomiler, emek piyasalarını esnekleştirmeden önce inovasyona yönelik politikaları istikrarlı ve tutarlı şekilde denemesi gerektiği söylenebilir. $\mathrm{Bu}$ açıdan devlet organizasyonu geleneksel bürokratik yapıdan modern girişimci bir şekilde, beşerî ve fiziki sermayelerini, liyakat prensibi başta olmak üzere, üretken alanlara tahsis etmelidir.

\section{KAYNAKÇA}

Aghion, P. ve Peter H. (1998). Endogenous Growth Theory. Cambridge, Massachusetts: The MIT Press.

Armingeon, K., \& Baccaro, L. (2012). Political economy of the sovereign debt crisis: The limits of internal devaluation. Industrial Law Journal, 41(3), 254-275.

Besson (2007.) TVA sociale, Secrétariat d'État chargé de la Prospective et de l'Évaluation des Politiques Publiques.

Bucovetsky, S. (1991). Asymmetric tax competition. Journal of urban economics, 30(2), 167-181.

Caprioli, F., Romanelli, M., \& Tommasino, P. (2017). Discretionary fiscal policy in the Euro area: past, present, future (No. 398). Bank of Italy, Economic Research and International Relations Area.

Cemy, P. G., \& Evans, M. (2000). New Labour, globalization, and the competition state. Center for European Studies Working Paper Series, 70. 
Cerny, P. G. (1996). Globalization and other stories: The search for a new paradigm for international relations. International Journal, 51(4), 617-637.

Cerny, P. G. (1997). Paradoxes of the competition state: the dynamics of political globalization. Government and Opposition, 32 (2), 251-274.

Dardot, P., \& Laval, C. (2014). The new way of the world: On neoliberal society. Verso Books.

De Grauwe, P. (2012). In Search of Symmetry in the Eurozone (No. 6901). Centre for European Policy Studies.

Doyle, C., \& Van Wijnbergen, S. (1994). Taxation of foreign multinationals: A sequential bargaining approach to tax holidays. International Tax and Public Finance, 1(3), 211-225.

EC (European Commission) (2015a). Supply and Demand Side Innovation Policies: Annexes of First Policy Brief, Publications Office of the European Union.

EC (European Commission) (2015b). Supply and Demand Side Innovation Policies: Annexes of Full Policy, Publications Office of the European Union.

Edler J. \& Georghiou L. (2007). Public Procurement and İnnovation-Resurrecting the Demand Side. Research Policy 36, 949-963.

Edwards, C., ve De Rugy, V. (2002). International Tax Competition: A 21st-Century Restraint on Government. Policy Analysis, No: 431, April 12.

Falk, M. (2007). R\&D Spending in the High-Tech Sector and Economic Growth. Research in Economics, 61 (3): 140147.

Fève, P., J. Matheron, ve J.-G. Sahuc (2009). La TVA sociale : bonne ou mauvaise idée, Banque de France Working Papers, No. 244.

Genschel, P., \& Seelkopf, L. (2014). The Competition State. The Oxford Handbook of Transformations of the State, 237-252.

Hohberger, S., \& Kraus, L. (2016). Is fiscal devaluation welfare enhancing?, Economic Modelling, 58, 512-522.

Hoyt, W (1991). Property taxation, Nash equilibrium, and market power. Journal of Urban Economics, 30, $23-31$.

Izsak, K. \& Edler, J. (2011). Trends and Challenges İn Demand-Side İnnovation Policies in Europe. Thematic Report 2011 under Specific Contract for the Integration of INNO Policy Trend chart with ERAWATCH (2011-2012), Technopolis Group

Jessop, B. (1993). Towards a Schumpeterian workfare state? Preliminary remarks on post-Fordist political economy. Studies in political economy, 40(1), 7-39.

Jessop, R. D. (2002). The future of the capitalist state. Cambridge: Polity.

Karmakar, K., \& Martinez-Vazquez, J. (2014). Fiscal Competition versus Fiscal Harmonization: A Review of the Arguments (No. paper1431). International Center for Public Policy, Andrew Young School of Policy Studies, Georgia State University.

Koske, I. (2013). Fiscal Devaluation - Can it help to Boost Competitiveness? OECD Economics Department Working Papers, No. 1089, OECD Publishing, Paris.

Madiès, T., \& Dethier, J. J. (2012). Fiscal competition in developing countries: a survey of the theoretical and empirical literature. Journal of International Commerce, Economics and Policy, 3(02), 1250013, 1-32

Meloni, W. P. (2017). Austerity \& Competitiveness in the Eurozone: a misleading linkage (No. 0223). Department of Economics-University Roma Tre.

Osborne, D. (1993). Reinventing government. Public productivity \& management Review, 349-356.

Pereira, A.M., Pereira, M.R., ve Rodrigues, G.P. (2014). On the Long-Term of a Fiscal Devaluation: An Application to the Portuguese Case, Chapter 6 in C. Amo-Yartley (Der.), Fiscal Policies: International Aspects, Short and LongTerm Challenges and Macroeconomic Effects içinde, Nova Publishers (forthcoming), New York, 1-25.

Pinder, S. (2011). Re-thinking the welfare state: Workfare and the question of 'rights-claims' for welfare recipients. Workfare and welfare state legitimacy, 161-189.

Roolaht, T. (2010). The Demand-Side İnnovation Policies in the Context of Small EU Member Country. Discussions on Estonian Economic Policy, 18, 404-427.

Sørensen, G. (1998). IR theory after the Cold War. Review of International Studies, 24(5), 83-100. 
Stockhammer, E., \& Sotiropoulos, D. P. (2014). Rebalancing the Euro area: the costs of internal devaluation. Review of Political Economy, 26(2), 210-233.

Taylor, M. (2010). Evolutions of the competition state in Latin America: power, contestation and neo-liberal populism. Policy Studies, 31(1), 39-56.

Theodoropoulou, S. (2016). Severe pain, very little gain: internal devaluation and rising unemployment in Greece, içinde Unemployment, internal devaluation and labour market deregulation in Europe (Ed: Martin Myant, Sotiria Theodoropoulou and Agnieszka Piasna), European Trade Union Institute, Brussels.

Torfing, J. (1999). Towards a Schumpeterian workfare postnational regime: path-shaping and path-dependency in Danish welfare state reform. Economy and Society, 28(3), 369-402.

Uxó, J., Paúl, J., \& Febrero, E. (2014). Internal devaluation in the European periphery: the story of a failure. Documentos de Trabajo.

Vis, B. (2007). States of welfare or states of workfare? Welfare state restructuring in 16 capitalist democracies, 19852002. Policy \& Politics, 35(1), 105-122.

Weisbrot, M., \& Ray, R. (2011). Latvia's internal devaluation: A success story?. Washington, DC: Center for Economic and Policy Research. http://www. cepr. net/index. php/publications/reports/latvias-internal-devaluationasuccess-story.

Wildasin, D. E. (2006). Fiscal competition. The Oxford Handbook of Political Economy. Oxford University Press, Oxford, 502-520.

Wilson, J. D., \& Wildasin, D. E. (2004). Capital tax competition: bane or boon. Journal of public economics, 88(6), 1065-1091.

Zodrow, GR ve Mieszkowski, P. (1986). Pigou, tiebout, property taxation and the underprovision of local public goods. Journal of Urban Economics, 19, 356-370. 